Research Article

\title{
Investigation of Preschool Preservice Teachers' Perceptions of Scientific Knowledge through Metaphor
}

\author{
Mehmet BARS *1 (D), Sedef SÜER 2 (D) \\ ${ }^{1}$ Dicle University, Ziya Gökalp Education Faculty, Department of Primary Education Sciences, Turkey mehmetbars21@gmail.com \\ 2 Dicle University, Ziya Gökalp Education Faculty, Department of Educational Sciences, Turkey sedefsuer@gmail.com \\ * Corresponding Author: mehmetbars21@gmail.com
}

\begin{tabular}{|c|c|}
\hline Article Info & Abstract \\
\hline $\begin{array}{l}\text { Received: } 28 \text { May } 2020 \\
\text { Accepted: } 04 \text { August } 2020\end{array}$ & $\begin{array}{l}\text { Scientific knowledge is a kind of objective knowledge, which is } \\
\text { systematic, valid, consistent, triable and provable. From this point of } \\
\text { view, the metaphoric perceptions of preservice teachers, who engaged } \\
\text { in many scientific knowledge and processes during the teachers' } \\
\text { training process, were found worthy of investigation in this study. This } \\
\text { study adopted the phenomenology study design. The sample consisted }\end{array}$ \\
\hline $\begin{array}{l}\text { Keywords: Scientific knowledge, } \\
\text { preschool, preservice teachers } \\
\text { metaphoric analysis }\end{array}$ & $\begin{array}{l}\text { of } 170 \text { preservice teachers studying in preschool education in a state } \\
\text { university during the } 2019-2020 \text { academic year. The questionnaire form } \\
\text { prepared by the researchers was used to find out the current } \\
\text { metaphorical perceptions of preservice teachers about the concept of }\end{array}$ \\
\hline doi $10.18009 /$ jcer.743743 & $\begin{array}{l}\text { 'scientific knowledge'. In this study, a total of } 139 \text { metaphors related to } \\
\text { scientific knowledge were created. Metaphors created by } 170 \text { preservice }\end{array}$ \\
\hline Publication Language: English & $\begin{array}{l}\text { teachers participating in the study were categorised based on their } \\
\text { commonalities and divided into nine categories. }\end{array}$ \\
\hline open 2 access & $\begin{array}{l}\text { To cite this article: Bars, M. \& Süer, S. (2020). Investigation of } \\
\text { preschool preservice teachers' perceptions of scientific knowledge } \\
\text { through metaphor. Journal of Computer and Education Research, } 8 \text { (16), } \\
608-630 \text {. DOI: } 10.18009 / \text { jcer.743743 }\end{array}$ \\
\hline
\end{tabular}

\section{Introduction}

Science, dating back to ancient times, is a field of activity that has emerged with the motivation of understanding, knowing and learning the world and the universe. Human beings have used the information that they obtained through the scientific process in different areas such as surviving, facilitating daily life tasks and dominating nature. The experience gained as a result of these efforts leads to the discovery of new information which, in the end, results in the growth of science like a snowball and the creation of different scientific fields. Another field of science which progresses through a cumulative process has been the transmission of discovered knowledge to the new generations. The need to transfer science and knowledge from generation to generation has led to the birth of education, which is also another field of scientific study. Each new knowledge in philosophy, logic, mathematics, biology, history and geography has been transferred to learners in educational institutions and schools. 
Originated from the Greek episteme and Latin scientia words, science refers to know something (Cevizci, 1999), knowledge generation process (Ziman, 2002), appropriate thinking and decision-making process (Ekiz, 2009). Science is defined as a regular piece of knowledge that tries to draw conclusions about a part of the universe or events based on experimental methods and reality (Dictionaries of Turkish Language Society (TDK), 2019). Scientific knowledge, archived by people and accepted as valid, has an objective soundness and the cause-effect relationship (Karasar, 2012). The definitions show that scientific knowledge is tackled as both a process and a product. As a product, science points to the knowledge obtained at the end of scientific methods and process (Cepni, 2012).

Three basic elements are stated to constitute the founding elements of knowledge. The first is the mind that is known as the subject of knowledge, the second is the object of knowledge and the third is the knowledge that emerges as a product of the relationship between these two elements (Cevizci, 2010).

The knowledge, which emerges as a result of the bond between the subject and object, is categorised under six types based on its characteristics and methods adopted. One of these is scientific knowledge (Cucen, 2012). Scientific knowledge is a kind of objective knowledge which is systematic, valid, consistent, triable and provable, which can be obtained on a particular subject by using the scientific methods. One of the highlighting features of scientific knowledge is being progressive (Lederman, Abd-El-Khalick, Bell \& Schwartz, 2002). According to the traditional approach, the scientific knowledge is objective and unbiased but guiding (Tekeli, 2002). As for the subjective approach, scientific knowledge is affected by individual judgements and choices as it is formed as a result of individual observations (Astley, 1985). The differences between the traditional and subjective approaches show that scientific knowledge has universal, consistent, objective and problemfree features, but, at the same time, it is inadequate and controversial, as well as it cannot find clear and distinct answers to important questions (Hodson, 2003).

Scientific knowledge has always been demanded throughout the history. It was found that people conducted the research and studies in the fields of mathematics, geometry, astronomy, biology, chemistry, geography, geology and philosophy even in the 2500s B.C. (http://tr.wikipedia.org/wiki/Bilim). In addition, ancient Greek thinkers such as Socrates and Plato attributed a great value to academic knowledge in the educational model as a way to establish a stable, safe and fair society. This system is seen as the basis of the traditional 
western curriculum (Popper, 1966). In today's information and digital society, although education has a close relationship with the latest developments in information and communication technologies, traditional discipline knowledge is stated to form the basis of the school curriculum (Gilbert, 2007). The curriculum was developed to provide the skills needed for the 21st century information society, 'Partnership for 21st Century Skills' emphasised that academic discipline knowledge should be included under the core school subjects (Partnership for 21st Century Skills, 2010). From this point of view, it is clearly understood that academic discipline knowledge obtained through scientific processes has been the cornerstone of education systems every time period, and scientific knowledge is tried to be transmitted to the learners under academic discipline knowledge through the courses in the curriculum.

Today, many developed countries in the world have been able to make scientific and technological advances, thanks to the scientific process, where they have obtained the knowledge and transmitted this knowledge to new generations in the educational context (Kola, 2013). This led the issue of training individuals in a way that they can assimilate science and scientific knowledge and use it in the real world in today's educational approach (Acat, Tuken \& Karadag, 2010). The schools during our days demand the students to work like a scientist and know how to produce knowledge and the methods of producing and verifying knowledge (Hodson, 2003), and this demand is observed even in the lowest level of educational institutions. The preschool education institutions and curriculum in Turkey, especially recommended to preschool teachers to carry out the concept studies, create science or science learning centres. These educational targets not only address the children's learning but also their scientific process skills which are improved with the help of providing opportunities for children to know the world they live in (Ministry of National Education, Preschool Curriculum (MoNE), 2018).

Scientific knowledge emerges as a result of individuals' interaction with the scientific process and context (Meichtry, 1999). Thus, teachers working in schools have the responsibility of providing students with such experience in a meaningful way (Gaffney, 2005). In fact, this situation is much more important in certain educational levels. When compared to the other levels, the teachers working in preschool education institutions are said to have much more impact on students' perception of science concepts (Senel \& Aslan, 2014). In this case, it is important to reveal the preservice teachers' perceptions about the 
scientific knowledge (Gurkan, Ozgun \& Kahraman, 2017). While transferring an abstract concept such as scientific knowledge to a very young learner group, the preschool teachers need to turn this concept into a more concrete structure that children can understand. With this perspective, the metaphor method can be an effective way to reveal the perceptions of preschool teachers. Hence, the use of a more tangible object to explain an abstract concept not only increases the effectiveness of the learning and teaching process (Pratte, 1981) but also contributes to the understanding and knowledge transfer obtained from the outside (Cosar, 2011). The metaphoric perceptions of preservice teachers, who are exposed to many scientific knowledge and processes in their training process, are thought to be worth exploring in this study.

This study aimed to reveal the preschool preservice teachers' perceptions of the scientific knowledge concept through the metaphor method. With this general aim, the following research questions were investigated:

- What kind of metaphors do preschool preservice teachers produce for the concept of scientific knowledge?

- How are the metaphors produced by preschool preservice teachers for the concept of scientific knowledge categorised?

\section{Method}

\section{Research Design}

This study, which aims to reveal the deep and detailed thoughts of preschool preservice teachers toward the concept of scientific knowledge, adopted the phenomenology study design. Phenomenology is a research design focusing on the meanings that people derive from their own life experiences or where the researchers try to derive the meaning from the other people's life experiences (Koopman, 2015).

\section{Study Group}

In this study, the participants were chosen by the criterion sampling method. In criterion sampling method, the participants are included in the study based on the predetermined criteria (Patton, 2014). The sampling criteria of this study were that preservice teachers should be recruited in preschool education department in the 2019-2020 academic year. Within the scope of this study, 170 preservice teachers were participated voluntarily in the study. The descriptive statistics results of the participants are shown in Table 1. 
Table 1. Descriptive statistics results of participants included in the study

\begin{tabular}{|c|c|c|c|c|c|}
\hline Gender & Female & Male & Total & & \\
\hline$N$ & 127 & 43 & 170 & & \\
\hline$\%$ & 74.7 & 25.3 & 100 & & \\
\hline Students & Freshman & Sophomores & Junior & Senior & Total \\
\hline$N$ & 40 & 28 & 63 & 39 & 170 \\
\hline$\%$ & 23.5 & 16.5 & 37.1 & 22.9 & 100 \\
\hline
\end{tabular}

Data Collection Tool

The questionnaire form prepared by the researchers was used to find out the current metaphorical perceptions of preservice teachers about the concept of 'scientific knowledge'. The questionnaire form was comprised of two personal questions (gender and grade level) and the statement 'Scientific knowledge is like/ similar Because ................' '. The draft questionnaire form was sent to three experts (in the field of psychological counselling and guidance, curriculum and development and measurement and evaluation). As a result of the feedback from the experts, the necessary revisions were made on the questionnaire form, and it was submitted to the approval of the ethics committee and then applied to preschool preservice teachers.

\section{Data Collection Process}

First, the general information about the metaphors was provided to the preservice teachers, and the preservice teachers were invited for participation in the study, which was completely voluntary. Then, the questionnaire form was handed out to the volunteer preservice teachers, and they were asked to write a metaphor and explain why they choose it. For this process, 20 minutes were allocated for preservice teachers, and any intervention was avoided in order not to impress participants' opinions. The main data source of the study consisted of these opinions written by the participants in their own handwriting.

\section{Data Analysis}

The data collected in this study were analysed by content analysis technique which is expressed as the determination of repetitive words or themes in a text obtained by a qualitative method (Patton, 2014). The content analysis was processed with a 5-step inductive content analysis method suggested in the relevant literature (Bektas \& Karadag, 2013). These five steps are as follows: (1) naming stage, (2) eliminating stage, (3) category development stage, (4) ensuring validity and reliability and (5) transferring data to the computer stage. 
1. Naming stage: At this stage, the metaphors produced by preservice teachers for the concept of 'scientific knowledge' were listed. Then, the sentences describing and explaining the metaphors were examined in terms of meaningfulness.

2. Eliminating stage: The consistency of the metaphors was ensured by examining the questionnaire forms filled by preservice teachers one by one in terms of image, subject and source. About 170 completed questionnaire forms were obtained.

3. Category development stage: The notes were taken about the metaphors produced by the preservice teachers for the concept of 'scientific knowledge' in line with considering what feature of this concept was taken. These notes were collected under common themes, and a new coding was made. The explanations of preservice teachers about the metaphors were read and placed in the relevant themes in line with the opinions of the researchers.

4. Ensuring validity and reliability: The questionnaire form used in the research was prepared in line with the conceptual framework as a result of the comprehensive examination made in the relevant literature, which was done to ensure the internal validity. In order to ensure the external validity, detailed information about the study group was presented (Miles, Huberman \& Saldana, 2014). To increase the internal reliability of the research, the research questions were expressed simply and understandably. In order to ensure external reliability (objectivity), all the processes performed during the research from the development of data collection tool to the data collection process and data analysis were described in detail. For the reliability of coding, the formula of consensus percentage $=$ (consensus / (consensus + disagreement) ${ }^{*}$ 100) suggested by Miles and Huberman (1994, p. 64) was used. The percentage of reliability calculated using this formula was found to be $94 \%$. When this percentage is converted to a reliability coefficient, the reliability coefficient was calculated as 0.94 . The coding made for this study can be said to be highly reliable since the coding is considered reliable if the Miles-Huberman reliability formula value is above 0.70 .

5. Transferring data to the computer stage: After determining the metaphors produced by teacher candidates and the conceptual categories containing these metaphors, the forms under each category were coded as PT1, PT2, PT33 PT170 and recorded to the computer. 


\section{Findings}

In this study, a total of 139 metaphors related to scientific knowledge were created by the preschool preservice teachers. Metaphors created by the participants were categorised based on their commonalities and divided into nine categories: (1) scientific knowledge as a need, (2) scientific knowledge as a dynamic structure, (3) scientific knowledge as an unchangeable-definitive structure, (4) scientific knowledge as a structure obtained as a result of the scientific process, (5) scientific knowledge as a structure that gives strength, selfconfidence and benefit, (6) scientific knowledge as a structure that needs effort and labour, (7) scientific knowledge as an infinite structure, (8) scientific knowledge as a cumulative structure and (9) 'scientific knowledge as an enlightening, guiding resource'. The distribution of the metaphors created by the preschool preservice teachers regarding the determined categories is shown in Table 2.

Table 2. The distribution of the metaphors created by the preschool preservice teachers regarding the determined categories

\begin{tabular}{lll}
\hline Categories & $f$ & $N$ \\
\hline Scientific knowledge as a need & 6 & 7 \\
Scientific knowledge as a dynamic structure & 21 & 24 \\
Scientific knowledge as an unchangeable-definitive structure & 25 & 27 \\
Scientific knowledge as a structure obtained as a result of the scientific process, & 13 & 14 \\
Scientific knowledge as a structure that gives strength, self-confidence and benefit & 13 & 16 \\
Scientific knowledge as a structure that needs effort and labour & 10 & 11 \\
Scientific knowledge as an infinite structure & 15 & 20 \\
Scientific knowledge as a cumulative structure & 14 & 14 \\
Scientific knowledge as an enlightening, guiding resource & 22 & 37 \\
\hline Total & 139 & 170 \\
\hline
\end{tabular}

It was found out that the most of the metaphors created by preschool preservice teachers were in the category of 'scientific knowledge as an unchangeable-definitive structure', and in this category, 27 preschool preservice teachers create 25 different metaphors, whereas the least metaphor was created in the category of 'scientific knowledge as a need' $(n=6)$, and in this category, seven preschool preservice teachers create only six different metaphors.

\section{Category 1. Scientific knowledge as a need}

In this category, 27 preschool preservice teachers create six different metaphors. When the content of these metaphors is examined, the preservice teachers were found to 
handle scientific knowledge as a basic need and perceive it positively. The metaphors and their frequencies created by the preservice teachers under this category are shown in Table 3.

Table 3. The metaphors created by preservice teachers under the category of 'scientific knowledge as a need'

\begin{tabular}{lll}
\hline Category & Metaphors & $\mathrm{f}$ \\
\hline & Nature & 2 \\
\multirow{3}{*}{ Scientific knowledge as a need } & Life & 1 \\
& Heat & 1 \\
& Hearth & 1 \\
& Water & 1 \\
& Food & 1 \\
\hline & Total & 7 \\
\hline
\end{tabular}

The metaphors created under the 'scientific knowledge as a need' category showed that preschool preservice teachers associate scientific knowledge with the items that are of great importance for human life such as nature (2), life (1), heat (1), heart (1), water (1) and food (1). Some of the metaphor expressions created under this category are as follows:

Scientific knowledge is similar to life. Because it is needed in the darkest and urgent times. It enlighten us...[PT40].

Scientific knowledge is similar to water. Because humanity needs scientific knowledge as much as water and we cannot give it up...[PT44].

Scientific knowledge is similar to food. Because people cannot live without it and will die without food. People will die without science either...[PT86].

\section{Category 2. Scientific knowledge as a dynamic structure}

In this category, 24 preschool preservice teachers create 20 different metaphors. When the content of these metaphors' is examined, the preservice teachers were found to handle scientific knowledge as a dynamic structure that is in constant change and development. The metaphors and their frequencies created by the preservice teachers under this category are shown in Table 4.

Table 4. The metaphors created by preservice teachers under the category of 'scientific knowledge as a dynamic structure'

\begin{tabular}{lll}
\hline Category & Metaphors & $\mathrm{f}$ \\
\hline & Tree & 1 \\
& Stone in a river & 1 \\
& Change & 1 \\
& World & 1 \\
& The age of the world & 1 \\
& Universe & 1 \\
& Sun in the sky & 1 \\
& Stars in the sky & 1 \\
Scientific knowledge as a & Beauty & 1
\end{tabular}




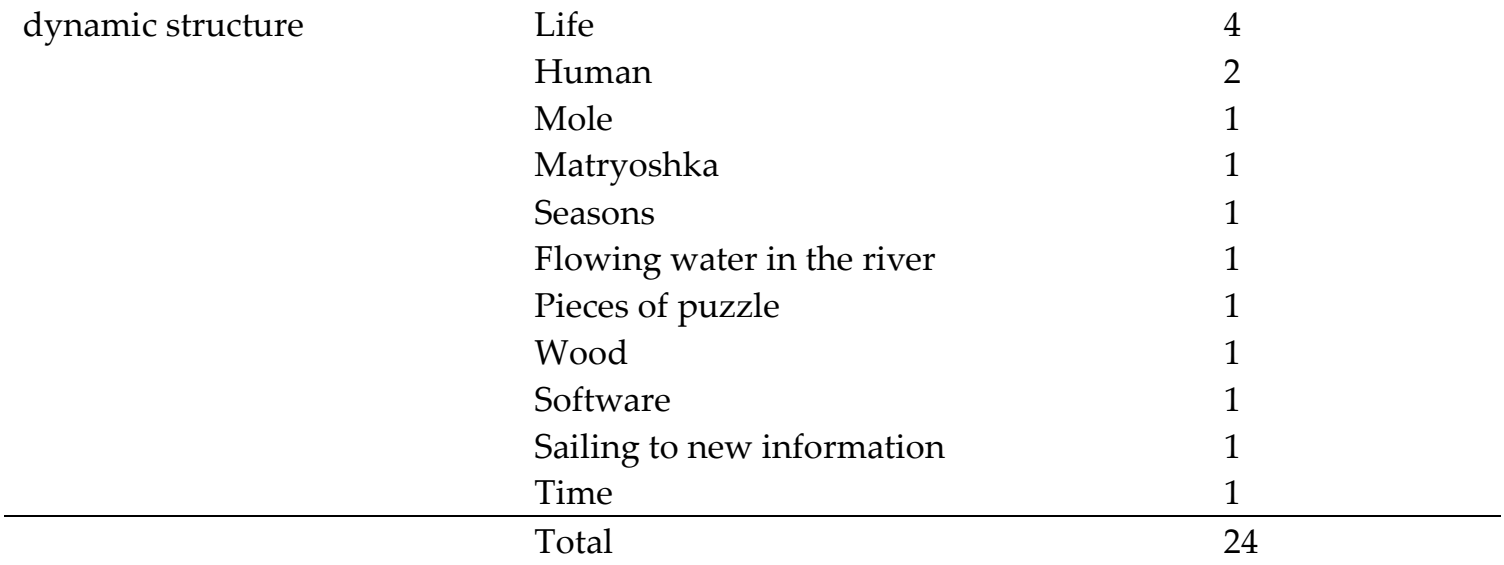

The metaphors created under the 'scientific knowledge as a dynamic structure' category showed that the preschool preservice teachers associate scientific knowledge with life (4), human (2), tree (1), world (1) and universe (1). Some of the metaphor expressions created under this category are as follows:

Scientific knowledge is similar to world. Because it is in constant development and transformation....[PT15].

Scientific knowledge is similar to life. Because it is in constant change and innovation. It is fed by both the past and the future, which constantly adds to it, like life....[PT58].

Scientific knowledge is similar to tree. Because it grows, turns green and becomes stable. But its development continues to be constantly renewed. Scientific knowledge is also put forward as an idea, and then becomes certain. It is then added further with new informations....[PT75].

Scientific knowledge is similar to matryoshka. Because; matryoshka contains multiple toys that are intertwined with each other. Scientific knowledge refers to more than one process that has intertwined with one another. Causes and consequences lead to the emergence of new knowledge, and this new knowledge leads to the new process, new causes and consequences. ....[PT118].

Category 3. Scientific knowledge as an unchangeable-definitive structure

In this category, 27 preschool preservice teachers create 25 different metaphors. When the content of these metaphors is examined, the preservice teachers were found to handle scientific knowledge as an unchangeable-definitive structure. The metaphors and their frequencies created by the preservice teachers under this category are shown in Table 5. 
Table 5. The metaphors created by the preservice teachers under the category of 'scientific knowledge as an unchangeable-definitive structure'

\begin{tabular}{|c|c|c|}
\hline Category & Metaphors & $f$ \\
\hline \multirow{25}{*}{$\begin{array}{l}\text { Scientific knowledge as an } \\
\text { unchangeable-definitive } \\
\text { structure }\end{array}$} & Tree & 1 \\
\hline & Academic knowledge & 1 \\
\hline & Atatürk's thoughts & 1 \\
\hline & Mirror & 1 \\
\hline & Accurate knowledge based on science & 1 \\
\hline & Living-unliving & 1 \\
\hline & A garment that cannot be changed & 1 \\
\hline & Nature & 1 \\
\hline & Best friend & 1 \\
\hline & Reality & 1 \\
\hline & Sun & 1 \\
\hline & Light & 1 \\
\hline & Book & 1 \\
\hline & Hourglass & 1 \\
\hline & A small child & 1 \\
\hline & Mathematics & 1 \\
\hline & Positive & 1 \\
\hline & Death & 1 \\
\hline & Guide & 1 \\
\hline & Concrete object & 2 \\
\hline & Sociology & 1 \\
\hline & Water & 2 \\
\hline & Poem & 1 \\
\hline & God & 1 \\
\hline & Technology & 1 \\
\hline & Total & 27 \\
\hline
\end{tabular}

The metaphors created under the 'scientific knowledge as an unchangeable-definitive structure' category showed that the preschool preservice teachers associate scientific knowledge with components such as water (2), mathematics (1), book (1), light (1) and nature (1). Some of the metaphor expressions created under this category are as follows:

Scientific knowledge is like a mirror. When a person looks in the mirror, s/he sees everything as it is. What is true and real are clear and concrete as in the case of scientific knowledge. It is concrete and real...[PT56].

Scientific knowledge is like the sun. Because; it is true and absolute, it is experienced in a same way by all. It is the same in everywhere.... [PT69].

Scientific knowledge is like the mathematic. Because; it is precise and objective....[PT147].

Category 4. Scientific knowledge as a structure obtained as a result of the scientific process 
In this category, 14 preschool preservice teachers create 13 different metaphors. When the content of these metaphors is examined, the preservice teachers were found to perceive scientific knowledge as a structure obtained as a result of the scientific process. The metaphors and their frequencies created by the preservice teachers under this category are shown in Table 6.

Table 6. The metaphors created by the preservice teachers under the category of 'scientific knowledge as a structure obtained as a result of the scientific process'

\begin{tabular}{lll}
\hline \multicolumn{1}{c}{ Category } & Metaphor & $\mathrm{f}$ \\
\hline & Brain & 1 \\
& A work done with a scientific process & 1 \\
& Life & 2 \\
Scientific knowledge as & Pencil & 1 \\
a structure obtained as a & Door & 1 \\
result of the scientific & Making table & 1 \\
process & Shuttling & 1 \\
& Objective method & 1 \\
& Sieve & 1 \\
& Poetic concepts & 1 \\
& Experience & 1 \\
& Theoretical knowledge becoming & 1 \\
\hline
\end{tabular}

The metaphors created under the 'scientific knowledge as a structure obtained as a result of the scientific process' category showed that the preschool preservice teachers associate scientific knowledge with components such as life (2), sieze (1), experience (1) and victory (1). Some of the metaphor expressions created under this category are as follows:

Scientific knowledge is like an experience. Because; the experiences we have in life lead us to science. We get scientific knowledge as a result of scientific processes....[PT24].

Scientific knowledge is like a door. Because; if you know where to open, you will definitely reach the place you have planned. You just need to know the what methods you will use, as in the knowledge. Just like knowing which key will open the right door....[PT46].

Scientific knowledge is like shuttling. Because; it is obtained through reason and experiment.... [PT136]. 
Category 5. Scientific knowledge as a structure that gives strength, self-confidence and benefit

In this category, 16 preschool preservice teachers create 13 different metaphors. When the content of these metaphors is examined, the preservice teachers were found to perceive scientific knowledge as a structure that gives strength, self-confidence and benefit. The metaphors and their frequencies created by the preservice teachers under this category are shown in Table 7.

Table 7. The metaphors created by preservice teachers under the category of 'scientific knowledge as a structure that gives strength, self-confidence and benefit'

\begin{tabular}{|c|c|c|}
\hline Category & Metaphors & $\mathrm{f}$ \\
\hline \multirow{14}{*}{$\begin{array}{l}\text { Scientific knowledge } \\
\text { as a structure that } \\
\text { gives strength, self- } \\
\text { confidence and benefit }\end{array}$} & Scientist's research result & 1 \\
\hline & Living body & 1 \\
\hline & Padishah's edict & 1 \\
\hline & Sun & 2 \\
\hline & Invention & 1 \\
\hline & Squash blossoms & 1 \\
\hline & Hand holding a pen & 1 \\
\hline & Clothes & 1 \\
\hline & Bird & 1 \\
\hline & Positive-negative & 1 \\
\hline & Infinity & 1 \\
\hline & Water & 3 \\
\hline & Volcanic eruption & 1 \\
\hline & Total & 16 \\
\hline
\end{tabular}

The metaphors created under the 'scientific knowledge as a structure that gives strength, self-confidence and benefit' category showed that the preschool preservice teachers associate scientific knowledge with components such as water (3), sun (2), bird (1) and clothes (1). Some of the metaphor expressions created under this category are as follows:

Scientific knowledge is like the squash blossoms. Because; when someone touches or takes care of squash, it blossoms and it emits beautiful pollen. Scientific knowledge also benefits everyone who goes into it.....[PT88].

Scientific knowledge is like the sun. Because; it opens up one's horizon and gives confidence....[PT98].

Scientific knowledge is like the water. Because; it is clear, clean and useful....[PT130].

Scientific knowledge is like the sun. Because; scientific knowledge makes people's daily lives easier and creates technological innovations in order to enable them to do their jobs comfortably and regularly ....[PT159]. 
Category 6. Scientific knowledge as a structure that needs effort and labour

In this category, 11 preschool preservice teachers create 10 different metaphors. When the content of these metaphors is examined, the preservice teachers were found to perceive scientific knowledge as a structure that needs effort and labour. The metaphors and their frequencies created by the preservice teachers under this category are shown in Table 8.

Table 8. The metaphors created by preservice teachers under the category of 'scientific knowledge as a structure that needs effort and labour'

\begin{tabular}{lll}
\hline Category & Metaphors & $\mathrm{f}$ \\
\hline & Tree & 2 \\
& Car & 1 \\
& Plant & 1 \\
Scientific knowledge & Glass & The egg the chick is trying to break \\
as a structure that & Diamond & 1 \\
needs effort and labor & Literal & 1 \\
& Hair & 1 \\
& Seed & 1 \\
& Time & 1 \\
& Total & 1 \\
\hline
\end{tabular}

The metaphors created under the 'scientific knowledge as a structure that needs effort and labour' category showed that the preschool preservice teachers associate scientific knowledge with components such as tree (2), diamond (1), glass (1) and seed (1). Some of the metaphor expressions created under this category are as follows:

Scientific knowledge is like a diamond. Because; before the diamond is formed, it is coal, it is processed and turns into a precious diamond through certain stages. ....[PT10].

Scientific knowledge is like glass. Because; if you wipe your glass, it shines. if you let it get dirty, you can't open it, you can't see outside....[PT124].

Scientific knowledge is like a seed. Because; knowledge starts with a step and we reach the most accurate one at the end of this process. Scientific knowledge goes through a process in which becomes accurate, precise and functional....[PT135].

Scientific knowledge is like a plant. Because; it grows as you work, process and labour....[PT161].

\section{Category 7. Scientific knowledge as an infinite structure}

In this category, 20 preschool preservice teachers create 15 different metaphors. When the content of these metaphors is examined, the preservice teachers were found to perceive 
scientific knowledge as an infinite structure. The metaphors and their frequencies created by the preservice teachers under this category are shown in Table 9.

Table 9. The metaphors created by preservice teachers under the category of 'scientific knowledge as an infinite structure'

\begin{tabular}{lll}
\hline Category & Metaphors & $\mathrm{f}$ \\
\hline & Nucleus & 1 \\
& Marsh & 1 \\
& Sea & 1 \\
& A bottomless pit & 1 \\
& World & 2 \\
Scientific knowledge & Universe & 2 \\
as an infinite structure & Objects in the galaxy & 1 \\
& Sky & 1 \\
& Blackhole & 1 \\
& Epic of Manas & 1 \\
& Oxygen & 1 \\
& Ocean & 4 \\
& Trees in forest & 1 \\
& Immense & 1 \\
& Outer space & 1 \\
\hline
\end{tabular}

The metaphors created under the 'scientific knowledge as an infinite structure' category showed that the preschool preservice teachers associate scientific knowledge with components such as ocean (4), universe (2), world (2) and oxygen (1). Some of the metaphor expressions created under this category are as follows:

Scientific knowledge is like a nucleus. Because; it seems simple at first, then you realise that it is an endless and immense road as you proceed...[PT2].

Scientific knowledge is like a outer space. Because; scientific knowledge is an endless knowledge. As people research, they understand that there is much more knowledge to learn...[PT27].

Scientific knowledge is like an ocean. Because as you research, examine, observe and experiment, it deepens like an immense ocean.... [PT43].

Scientific knowledge is like the sky. Because no matter where you look from, it looks immense and when you look from afar, you think you suppose it gets closer, but no matter how long you go, it will always get away from you. You can only reach it in certain ways like in the case of scientific knowledge. Its scope is wide and can be managed by certain methods....[PT79]. 


\section{Category 8. Scientific knowledge as a cumulative structure}

In this category, 14 preschool preservice teachers create 14 different metaphors. When the content of these metaphors is examined, the preservice teachers were found to perceive scientific knowledge as a cumulative structure. The metaphors and their frequencies created by the preservice teachers under this category are shown in Table 10.

Table 10. The metaphors created by preservice teachers under the category of 'scientific knowledge as an infinite cumulative'

\begin{tabular}{lll}
\hline Category & Metaphors & $\mathrm{f}$ \\
\hline & Tree & 1 \\
& Planetree & 1 \\
& Experience & 1 \\
& Seaside sands & 1 \\
& Universe & 1 \\
Scientific knowledge & Sky & 1 \\
as a cumulative & See & 1 \\
structure & Pearl & 1 \\
& Cancer cell & 1 \\
& Snowflake & 1 \\
& Snowball & 1 \\
& Books & 1 \\
& Itinerant & 1 \\
& Earth & 1 \\
\hline & Total & 14 \\
\hline
\end{tabular}

The metaphors created under the 'scientific knowledge as a cumulative structure' category showed that preschool preservice teachers associate scientific knowledge with components such as tree (1), plane tree (1), sky (1) and pearl (1). Some of the metaphor expressions created under this category are as follows:

Scientific knowledge is like a plane tree. Because; scientific knowledge must have a basis and a certain accumulation process. Scientific knowledge has its roots in the oldest times. It grows and develops as new knowledge come out....[PT3].

Scientific knowledge is like the universe. Because; the universe continues to expand. Scientific knowledge continues to expand by constantly putting on one another and accumulation gets bigger....[PT60].

Scientific knowledge is like the sky. Because; the sky is formed by combining different and small pieces. Scientific knowledge also develops with the accumulation and transfer of knowledge... [PT68].

Scientific knowledge is like a snowball. Because; it is cumulative, that is, it progresses in a cumulative way. Each study helps to discover new codes of science and to reveal unknown mysteries.... [PT97]. 
Category 9. Scientific knowledge as an enlightening, guiding resource

In this category, 37 preschool preservice teachers create 22 different metaphors. When the content of these metaphors is examined, the preservice teachers were found to perceive scientific knowledge as an enlightening, guiding resource. The metaphors and their frequencies created by the preservice teachers under this category are shown in Table 11.

Table 11. The metaphors created by preservice teachers under the category of 'scientific knowledge as an enlightening, guiding resource'

\begin{tabular}{lll}
\hline Category & Metaphors & $\mathrm{f}$ \\
\hline & A charming book & 1 \\
& Aquarium & 1 \\
& Mother & 2 \\
& Encyclopaedia & 1 \\
& Atmosphere & 1 \\
& Moon & 1 \\
& Enlightening tool & 2 \\
Scientific knowledge & Father & 1 \\
as an enlightening, & Magnifying glass & 1 \\
guiding resource & Lighthouse & 2 \\
& Sun & 7 \\
& Map & 1 \\
& Light & 5 \\
& Lodestar & 1 \\
& Dogs & 1 \\
& Book & 1 \\
& Pole star & 1 \\
& Lamp & 1 \\
& School & 1 \\
& A shining star & 1 \\
& Compass & 3 \\
& The small hours & 1 \\
\hline
\end{tabular}

The metaphors created under the 'scientific knowledge as an enlightening, guiding resource' category showed that the preschool preservice teachers associate scientific knowledge with components such as sun (7), light (5), sky (1), compass (3), lighthouse (2) and mother (2). Some of the metaphor expressions created under this category are as follows:

Scientific knowledge is like a father. Because; whenever we are in difficulty or in trouble, it shows us the right option. We always need its existence...[PT5].

Scientific knowledge is like the sun. Because; it shines around and lets us see our way...[PT8]. 
Scientific knowledge is like the light. Because; like a light, it illuminates the people and saves them from darkness....[PT13].

Scientific knowledge is like a compass. Because; it guides everything... [PT53].

Scientific knowledge is like a mother. Because; nothing can be done without it. Scientific knowledge helps us from birth to death.... [PT72].

\section{Discussion and Conclusion}

The metaphors produced by the preservice teachers were determined to be similar to those created for the concept of 'science' and 'knowledge' (Biyikli, Basbay \& Basbay, 2014; Gurkan, Ozgün \& Kahraman, 2017; Saban, 2008; Senel \& Aslan, 2014). Within the scope of the research, most of the metaphors created by preschool preservice teachers were found to be in the category of 'scientific knowledge as an unchangeable-definitive structure', and this category included 25 out of 139 metaphors created in total. As the preschool preservice teachers produce the positive metaphors for scientific knowledge, it can be interpreted as they generally have a positive perception about scientific knowledge.

It has been determined that the preschool preservice teachers have the opinion that the needs are the main factor for the production of scientific knowledge. This perception is thought to arise mainly from the view that scientific need is one of the determining factors that leads to the emergence of scientific knowledge. In the 2500s B.C, ancient people were determined to conduct the research and studies in the fields of mathematics, geometry, astronomy, biology, chemistry, geography, geology and philosophy (http://tr.wikipedia.org/wiki/Bilim), and they used the knowledge that they obtained to carry out daily life activities such as hunting, trade and agriculture (Singer, 2013). In this concept, human needs are considered as a determining factor for the emergence of scientific knowledge (Arik, 2019).

It has been determined that the preschool preservice teachers have the opinion that scientific knowledge can only be accessed with the use of scientific processes. In the teacher training course called scientific research methods in education, a unit or theme is generally allocated for the definitions about the concepts of science and scientific knowledge. These definitions frequently emphasise the scientific processes and methods. For instance, Cepni (2012) defined the science as a handling of scientific process and products within the logic rules, Ekiz (2009) defined the science as the process of obtaining information with appropriate methods and data collection tools and Arslan (1999) defined the scientific 
knowledge as systematic, orderly, valid, consistent, provable, testable and objective type obtained as a result of scientific methods. The preschool preservice teachers have stated that scientific knowledge has an unchangeable structure. Cepni (2012) stated that scientific knowledge is based on data obtained through objective methods and processes, and thus, this knowledge has a feature that cannot be change from one person to another and from one society to another. This point of view supports the positivist statement that scientific knowledge is objective. The positivism suggests that there is only one real knowledge that is scientific knowledge, and all other knowledge except the scientific one cannot be testable and provable (Hughes, 2010).

The preschool preservice teachers have the opinion that scientific knowledge has a dynamic structure. Lederman (1983) stated that science is a dynamic and on-going activity rather than a static knowledge accumulation. Thus, scientific knowledge obtained through scientific processes has also been thought to have a dynamic structure. Gaffney (2005) stated that scientific knowledge is durable but open to change. Since the life around us witnesses an important and rapid change (Hodson, 2003), science and scientific knowledge appears as a part or a reason for this change. Any knowledge produced in science may lose its validity in 10 years or may raise new questions (Weber, 1946). As a result of new knowledge and theories discovered, the existing knowledge may lose its validity, so scientific knowledge is open to change (Schwartz \& Lederman, 2002).

The preschool preservice teachers have stated that scientific knowledge has a cumulative feature. The most important feature of scientific knowledge is its being progressive (Arslan, 1999), i.e., it progress from past to future cumulatively (Ekiz, 2009). The scientific studies are based on the past studies, i.e., a new knowledge is formed on the basis of knowledge obtained by others. Therefore, the knowledge obtained in science is accepted as the products of the past (Mendelsohn, 2012). The questions that guide scientific research and the scientists who put forth these questions have indicated that the science is always obtained as a result of the joint efforts of the larger society and culture, where it is applied (Bartos \& Lederman, 2014).

The preschool preservice teachers have stated that scientific knowledge has an infinite structure. In the study conducted by Senel and Aslan (2014), the preschool preservice teachers have been determined to state that the concept of science has a wide-infinite structure. Gurkan, Ozgun and Kahraman (2017) in their study found that preservice teachers 
handle the knowledge as a wide-infinite structure. When the preservice teachers' statements were analysed, the preservice teachers generally used such expressions as ...it seems simple at first, then you realise that it is an endless and immense road as you proceed...[PT2]....As people research, they understand that there is much more knowledge to learn...[PT27]....As you research, examine, observe and experiment, it deepens like an immense ocean.... [PT43]. These statements show that the preservice teachers emphasised the existence of much more scientific knowledge than they really think.

The preschool preservice teachers deal with the scientific knowledge as a structure that gives strength, self-confidence and benefit. Knowledge is the most important criterion that distinguishes humans from other living things. Today, many living creatures in the world fulfil their development through their instincts, which is not the same for human beings (Mengusoglu, 1988). What is the most important key for the development of human beings is knowledge (Yilmaz, 1998). For this reason, it can be thought that the knowledge gained through scientific processes leads to a quality that improves human life, benefits it, helps it, gains strength and thus develops confidence toward it.

The preschool preservice teachers handle the scientific knowledge as a structure that needs effort and labour. In the study carried out by Biyikli, Basbay and Basbay (2014), middle school and high school students stated that science was realised as a result of endeavouring. In the study carried out by Gurkan, Ozgun and Kahraman (2017), the preservice teachers stated that knowledge emerged as a result of effort and labour. When the related literature was examined, the knowledge obtained at the end of scientific processes was frequently handled as a product of the human being's common effort (Ekiz, 2009). These statements may have led the preservice teachers to think that scientific knowledge requires effort and labour.

The preschool preservice teachers have the opinion that scientific knowledge acts as an enlightening, guiding resource. In the studies carried out by Saban (2008) and Gurkan, Ozgun and Kahraman (2017), the participants were determined to handle the scientific knowledge as enlightening, guiding resource. This perception may have resulted from the fact that science and scientific knowledge played a key role for the ending of dark periods and illuminating role in the history of humankind. For example, medieval people got rid of pressure and misapplication, thanks to science, and made groundbreaking scientific discoveries and inventions such as geographical discoveries and printing (Akarsu, 2017). 
This historical information is frequently presented to preservice teachers in Scientific Research Methods in Education coursebooks (Cepni, 2012; Ekiz, 2009), and this may led the preservice teachers to attribute the guiding and enlightening role of science to scientific knowledge. This can be supported with the relevant literature. Since scientific knowledge has a feature of objectivity, it has to meet a number of criteria such as being universal, guiding life, being testable with facts in outer world and being falsifiable. For this reason, it is stated that scientific knowledge claims to lead and guide the life (Tekeli, 2002).

When the metaphors created by preservice teachers for the concept of scientific knowledge were analysed, it was seen that these metaphors are generally similar to those created for the concept of 'science' and 'knowledge' (Biyikli, Basbay \& Basbay, 2014; Gurkan, Ozgun \& Kahraman, 2017; 2008b; Senel \& Aslan, 2014). This shows that the preservice teachers make use of their knowledge about the 'nature of science' and 'science' while explaining scientific knowledge. Indeed, this is a general feature of metaphor studies, where the features of something unknown are tried to be explained with the help of the feature of something known. That is, an abstract concept is explained and expressed with the help of more concrete objects and concepts (Burke, 1992). The similar understanding also exists in the scientific literature, and although it expresses two different dimensions, the nature of science and the nature of scientific knowledge are used interchangeably. In fact, science and scientific knowledge do not mean the same thing. While science is an activity that people perform to understand and explain a phenomenon, scientific knowledge is the product obtained as a result of this process. Scientific knowledge is the result of human interaction with scientific activity and social context (Meichtry, 1999). Creativity plays an important role in the process of scientific knowledge, but laws and theories are also used. In addition, although science emphasises the objectivity, there is subjectivity in the formation of scientific knowledge. Thus, it is the product of a relationship between observations and inferences (NSTA, 2000). The metaphors created by the preservice teachers regarding scientific knowledge indicate that preservice teachers have a lack of knowledge or misconceptions about the concept of scientific knowledge as they do not mention the above-mentioned descriptions and explanations. In this case, it is recommended that prospective teachers studying at teachers training institutions should be exposed to clearer, descriptive and explanatory learning activities and processes related to scientific knowledge. 
Acknowledgement

The data used in this study was confirmed by the researchers that it belongs to the year of 2020.

Ethics Committee Permit Information

Name of the board that carries out ethical evaluation: Dicle University Social Sciences Ethics Committee

The date of the ethical assessment decision: 03/03/2020

Ethical assessment document number number: 2020/27995

Authorship Contribution Statement

Mehmet BARS: Conceptualization, data collection, design of the work, data analysis, writing - review and editing.

Sedef SüER: Conceptualization, preliminary analyses, data interpretation, writing, manuscript revision.

\section{References}

Acat, M. B., Tuken, G. \& Karadag, E. (2010). The scale of scientific epistemological beliefs: Adapting for Turkish culture, language validity and examination of factor structure. Journal of Turkish Science Education, 7(4), 67-89.

Akarsu, B. (2017). Bilim dunu, bugunu, yarini (bilimin dogasi ve bilim tarihi) [Science yesterday, today, tomorrow (Nature of science and history of science)]. Retrieved from https://www.researchgate.net/publication/326410237_Bilim_Dunu_Bugunu_Yarini_Bili min_Dogasi_ve_Bilim_Tarihi/citations

Arik, R. S. (2019). Arastirma yontemleriyle ilgili temel kavramlar ve ilkeler. In K. Yilmaz \& R. S. Arik. (Eds), Egitimde araştırma yontemleri [Research methods in education] (pp. 2-26). Ankara, Turkey: Pegem A Yayincilik.

Arslan, A. (1999). Felsefeye giris [Introduction to philosophy] (4th ed.). Ankara, Turkey: Vadi Yayınlari.

Astley, W G: (1985). "Administrative science as socially constructed truth". Administrative Science Quarterly, 30(4), 497-513.

Bartos, S. A. \& Lederman, N. G. (2014). Teachers' knowledge structures for nature of science and scientific inquiry: Conceptions and classroom practice. Journal of Research in Science Teaching, 51(9), 1150-1184.

Bektas, M. \& Karadag, B. (2013). The analysis of metaphors that primary school 4. grade students developed for cooperating value. Turkish Studies - International Periodical for the Languages, Literature and History of Turkish or Turkic, 8(8), 271-286. 
Biyıklı, C., Basbay, M. \& Basbay, A. (2014). Secondary and high school students' metaphors about the concept of science. Abant Izzet Baysal Universitesi Egitim Fakultesi Dergisi, 14(1), 413-437.

Burke, W. W (1992). Metaphors to consult by. Group and Organization Management, 17(3), 255-259.

Cevizci, A. (1999). Felsefe sozlugu [Philosophical dictionary]. Istanbul, Turkey: Paradigma Yay..

Cevizci, A. (2010). Bilgi felsefesi [Philosophy of knowledge]. Istanbul, Turkey: Say Yayinlari.

Cosar, M., (2001). Nietzsche felsefesinde durtu ve metafor kavramları. [Impulse and metaphor concepts in Nietzsche philosophy]. Felsefe Dunyasi [World of philosophy], 1(33), 83-90.

Cepni, S. (2012). Arastirma ve proje calismalarina giris [Introduction to research and project studies]. Trabzon: Celepler Matbaacilik.

Cucen, A. (2012). Bilgi felsefesi [Philosophy of knowledge] (4th ed.). Istanbul, Turkey: Sentez Yayincilik.

Ekiz, D. (2009). Bilimsel arastirma yontemleri [Scientific research methods]. Ankara, Turkey: Ani Yayincilik.

Gaffney, J. (2005). The importance of science literacy in modern culture. Retrieved from http://www.phyast.pitt.edu/ jgaffney/scilit.pdf

Gilbert, J. (2007). Knowledge, the disciplines, and learning in the digital age. Educational Research for Policy and Practice, 6(2), 115-122.

Gurkan, G., Ozgun, B. B. \& Kahraman, S. (2017). Preservice teachers' metaphoric perceptions about knowledge concepts. Inonu University Journal of the Graduate School of Education, $4(8), 1-18$.

Hodson, D. (2003). Time for action: science education for an alternative future. International Journal of Science Education, 25(6), 645-670.

Hughes, P. (2010). Paradigms, methods and knowledge. In G. M. Naughon, S. A. Rolfe \& I. Siraj-Blatchford (Eds), Doing early childhood research: international perspectives on theory and practice (2nd ed., pp. 35-61). New York: Open University Press.

Karasar, N. (2012). Bilimsel arastirma yontemleri [Scientific research methods]. Ankara, Turkey: Nobel Yayincilik.

Kola, A. J. (2013). Importance of science education to national development and problems militating against its development. American Journal of Educational Research, 1(7), 225-229.

Koopman, O. (2015). Phenomenology as a potential methodology for subjective knowing in science education research. Indo-Pacific Journal of Phenomenology, 15(1), 1-10.

Lederman, N. G., Abd-El-Khalick, F., Bell, R. L. \& Schwartz, R. S. (2002). Views of nature of science questionnaire: toward valid and meaningful assessment of learners' conceptions of nature of science. Journal of Research in Science Teaching, 39(6), 497-521.

Lederman, N. G. (1983). Delineating classroom variables related to students' conception of the nature of science. Dissertation Abstracts International, 45, 483A (University Microfilms No. 84-10, 728).

Ministry of National Education (MoNE). (2018). Okul oncesi ogretim programı [Preschool curriculum]. Retrieved from http://mufredat.meb.gov.tr 
Mendelsohn, E. (2012). The social construction of social knowledge. In E. Mendelsohn, P. Weingart \& R. D. Whitely (Eds.), The social production of scientific knowledge: Yearbook (pp. 3-26). Berlin, Germany: Springer Science \& Business Media.

Mengusoglu, T. (1988). Insan felsefesi [Human philosophy]. Istanbul, Turkey: Remzi Kitabevi.

Meichtry, Y. J. (1999). The nature of science and scientific knowledge: Implications for a preservice elementary methods course. Science E Education, 8(3), 273-286.

Miles, M. B. \& Huberman, A. M. (1994). Qualitative data analysis (2nd ed.). Thousand Oaks, CA: Sage Publications.

Miles, M. B., Huberman, A. M. \& Saldana, J. (2014). Qualitative data analysis: a method sourcebook (3rd ed.). Thousand Oaks, CA: Sage Publications.

National Science Teachers Association. (2000). NSTA position statement: the nature of science. Retrieved from http://www.nsta.org/159\&psid=22.

P21 (2010), Partnership for 21st century skills, 2010. Retrieved from http://www.p21.org.

Patton, M. Q. (2014). Nitel arastirma ve degerlendirme yontemleri [Qualitative research and evaluation methods]. In M. Butun \& S. B. Demir (Cev Eds.). Ankara, Turkey: Pegem Akademi.

Popper, K. (1966). The open society and its enemies: volume one the spell of Plato. London, UK: Routledge and Kegan Paul.

Pratte, R. (1981). Metaphorical models and curriculum theory. Curriculum Inquiry, 11(4), 307-320.

Saban, A. (2008). Primary school teachers' and their students' mental images about the concept of knowledge. Elementary Education Online, 7(2), 421-455.

Schwartz, R. S. \& Lederman, N.G. (2002). "It's the nature of the beast": The influence of knowledge an intentions on learning and teaching nature of science. Journal of Research in Science Teaching, 39(3), 205-236.

Singer, C. (2013). A short history of science to the nineteenth century. Oxford, UK: Clarendon Prs.

Senel, T. \& Aslan, O. (2014). The metaphoric perceptions of preservice early childhood teachers' conceptions on science and scientist. Mersin University Journal of the Faculty of Education, 10(2), 76-95.

TDK (2019). Dictionaries of Turkish Language Society. Retrieved from https://sozluk.gov.tr/

Tekeli, I. (2002). Bilgi toplumuna geçiş [Transition to the information society]. Ankara, Turkey: Turkiye Bilimler Akademisi Yayinlari.

Weber, M. (1946). Science as a vocation. In Alfred I. Tauber(Ed) Science and the quest for reality (pp. 382-394). London, UK: Palgrave Macmillan.

Yilmaz, B. (1998). "Information society": a critical approach. Journal of Faculty of Letters, 15(1), 147-158.

Ziman, J. (2002). Real science: what it is and what it means. Cambridge, UK: Cambridge University Press.

JCER's Publication Ethics and Publication Malpractice Statement are based, in large part, on the guidelines and standards developed by the Committee on Publication Ethics (COPE). This article is available under Creative Commons CC-BY 4.0 license (https://creativecommons.org/licenses/by/4.0/) 